\title{
Nano zinc oxide - An alternate zinc supplement for livestock
}

\author{
K. Geetha ${ }^{1}$, M. Chellapandian ${ }^{2}$, N. Arulnathan ${ }^{2}$ and A. Ramanathan ${ }^{3}$
}

1. Nanotechnology Division, Periyar Maniammai Institute of Science and Technology, Thanjavur, Tamil Nadu, India; 2. Department of Animal Nutrition, Veterinary College and Research Institute, Tirunelveli, Tamil Nadu, India; 3. Department of Animal Husbandry, School of Agriculture and Animal Sciences, Gandhigram Rural Institute, Dindigul, Tamil Nadu, India.

Corresponding author: A. Ramanathan, e-mail: ramanathangri@gmail.com

Co-authors: KG: rktgeetha@gmail.com, MC: mcpandian69@gmail.com, NA: drarulnutri@gmail.com

Received: 26-09-2019, Accepted: 05-12-2019, Published online: 16-01-2020

doi: www.doi.org/10.14202/vetworld.2020.121-126 How to cite this article: Geetha K, Chellapandian M, Arulnathan N, Ramanathan A (2020) Nano zinc oxide - An alternate zinc supplement for livestock, Veterinary World, 13(1): 121-126.

\begin{abstract}
Aim: This study was aimed to investigate antimicrobial and cytotoxicity effect of nano $\mathrm{ZnO}$ in in vitro for the application of livestock feed supplement.

Materials and Methods: Nano $\mathrm{ZnO}$ was synthesized by wet chemical precipitation method using zinc acetate as a precursor and sodium hydroxide was used for reducing the precursor salt. The properties of synthesized powder were characterized using ultraviolet (UV)-visible spectroscopy, Fourier transform infrared (FTIR), scanning electron microscopy (SEM), and X-ray diffraction (XRD), respectively. In vitro antimicrobial activities were analyzed against the pathogenic bacteria in poultry Escherichia coli, Staphylococcus aureus, Klebsiella pneumoniae, and Streptococcus aeruginosa. 3-(4,5-dimethylthiazol-2-yl)-2,5-diphenyltetrazolium bromide assay was conducted to analyze the cytotoxicity effect of nano $\mathrm{ZnO}$.
\end{abstract}

Results: SEM showed a spherical $\mathrm{ZnO}$ particle in the range of 70-100 nm. The size of the particle and purity of the sample were confirmed by XRD. The nano-sized ZnO particles exhibited the UV absorption peak at $335 \mathrm{~nm}$. In FTIR spectroscopy, pure $\mathrm{ZnO}$ nanoparticles showed stretching vibrations at $4000-5000 \mathrm{~cm}^{-1}$. ZnO nanoparticles exhibited remarkable antibacterial activity against $E$. coli, $S$. aureus, $K$. pneumoniae, and $S$. aeruginosa bacterial strains. Cell viability was significantly reduced in a dose-dependent manner in the cytotoxicity study.

Conclusion: From the broad-spectrum antibacterial activity and the lower cytotoxicity observed at the prescribed dose, it is concluded that nano $\mathrm{ZnO}$ powder is a potential alternate zinc supplement for livestock.

Keywords: antimicrobial, cytotoxicity, nano zinc oxide, precipitation method, zinc supplementation.

\section{Introduction}

Zinc is the second most essential trace element in all living systems from animals to humans, plays an essential role in many metabolic processes of the body [1]. The daily dietary intake of zinc is essential to regulate the cell division by regulating the synthesis of protein and DNA [2]. The two predominant sources of $\mathrm{Zn}$ used by the animal feed industry are $\mathrm{ZnO}$ and $\mathrm{ZnSO}_{4} \cdot \mathrm{H}_{2} \mathrm{O}$ [3]. Deficiency of zinc in cattle leads to improper growth, reduced feed intake, reduced milk yield, and decreases of cycling and conception rate $[4,5]$. Milk yield increased when $\mathrm{Zn}$ is supplemented in the form of zinc methionine or zinc lysine to the cattle [6]. The National Research Council recommended $30 \mathrm{ppm}(\mathrm{mg} / \mathrm{kg})$ as the dietary requirement of zinc on a dry matter basis for cattle. Supplementation of nano zinc drastically reduced somatic cell count in milk from cows with subclinical

Copyright: Geetha, et al. Open Access. This article is distributed under the terms of the Creative Commons Attribution 4.0 International License (http://creativecommons.org/licenses/ by/4.0/), which permits unrestricted use, distribution, and reproduction in any medium, provided you give appropriate credit to the original author(s) and the source, provide a link to the Creative Commons license, and indicate if changes were made. The Creative Commons Public Domain Dedication waiver (http:// creativecommons.org/publicdomain/zero/1.0/) applies to the data made available in this article, unless otherwise stated. mastitis and improved milk production than cows supplemented with macro zinc oxide [7,8]. Zinc deficiency in lamb results in slipping of wool, decreased growth and improper growth of testes [9], weight loss during lactation, development of skin lesions, and excessive salivation [10]. Elevation of phytate by poor intestinal absorption of zinc from improper zinc supplement ends in prolonged enteritis and dermatosis [11]. Continuous supplementation of zinc in the form of zinc sulfate $(10 \mathrm{mg} / \mathrm{kg} /$ day $)$ or zinc methionate $(1.7 \mathrm{mg} / \mathrm{kg} /$ day $)$ is normally required for maintenance [12]. Zinc plays with disease resistance, cellular immunity, spleen development, and alteration in high-density lipoprotein cholesterol in poultry $[13,14]$. The supplemental zinc used in poultry is zinc sulfate or zinc chloride [15]. Zinc in the form of $\mathrm{Zn}$ methionine shows greater biological availability than zinc from inorganic sources [16]. The recommended level of zinc in various poultry diets ranges from 40 to $75 \mathrm{ppm}[17]$.

Zinc oxide is the most commonly used zinc supplement with high antibacterial activity, antifungal, and growth promoter ability [18]. Zinc oxide generates hydrogen peroxide which can pass through the cell wall, disrupt metabolic process, and, in turn, inhibit the microbial growth. The affinity of zinc 
oxide toward the bacterial cell is the most important factor for antibacterial activity [19]. It reduces zinc deficiency and its results to reduce growth retardation and lower rate of infertility [20]. However, the bioavailability of $\mathrm{ZnO}$ can be enhanced by changing the size effect. The reduced size of $\mathrm{ZnO}$ in nanoscale will enhance the bioavailability by increased ionization of zinc. Commonly organic zinc resources are resulted with good results due to the higher bioavailability in all livestock growth and production. However, the production cost and supplementation dose rate are not sufficient to make artificial farming in a cost-effective manner. The nano $\mathrm{ZnO}$ can produce a positive effect to overcome the zinc deficiency problem with cost-effective and lower dose rate.

We hypothesized that the higher bioavailability of nano $\mathrm{ZnO}$ can easily absorb from the intestine and interferes with subcellular mechanisms. Moreover, the highest antibacterial effect with different bacterial species was reported in recent works. Nano $\mathrm{ZnO}$ in feed mixture will provide the dual function of a $\mathrm{Zn}$ supplement and as an antimicrobial agent during feed storage. To test this supposition, we have synthesized the nano $\mathrm{ZnO}$ by wet chemical precipitation method at $80^{\circ} \mathrm{C}$ using zinc acetate. The confirmation of nano $\mathrm{ZnO}$ presence, concentration, morphology, and particle size is characterized using ultraviolet (UV)-visible spectroscopy, Fourier transform infrared (FTIR), scanning electron microscopy (SEM), and X-ray diffraction (XRD), respectively. Antimicrobial effect against Escherichia coli, Staphylococcus aureus, Klebsiella pneumoniae, and Streptococcus aeruginosa in in vitro level was evaluated by antibacterial disk diffusion test. MTT cytotoxicity assay was carried out to determine the biocompatibility and cytotoxic effect of nano $\mathrm{ZnO}$.

\section{Materials and Methods \\ Ethical approval}

No Ethical Committee approval was necessary for this study as we conducted experiment in vitro.

\section{Precipitation method}

The zinc oxide nanoparticles were synthesized using zinc acetate as the precursor and sodium hydroxide as the reducing agent. A $0.1 \mathrm{M}$ of zinc acetate homogenous mixture was dissolved in double-distilled water at $\mathrm{pH}$ of 11 for $2 \mathrm{~h}$ with the aid of magnetic stirrer. The $0.1 \mathrm{M} \mathrm{NaOH}$ solution was slowly added into the zinc acetate solution under continuous stirring. The final solution was stirred for $4 \mathrm{~h}$ at $\mathrm{pH}$ of 7. The final precipitate was filtered with Whatman No.1 filter paper and then the colloidal zinc oxide was lyophilized. Then, the powdered zinc oxide nanoparticles were collected and stored for further process.

$\mathrm{Zn}\left(\mathrm{CH}_{3} \mathrm{COO}\right)_{2}+2 \mathrm{NaOH} \rightarrow \mathrm{Zn}(\mathrm{OH})_{2}+2 \mathrm{CH}_{3} \mathrm{COONa}$

$\mathrm{Zn}(\mathrm{OH})_{2} \rightarrow \mathrm{ZnO}+\mathrm{H}_{2} \mathrm{O}$

\section{Characterization}

The obtained samples were characterized by powder XRD method with $\mathrm{CuK} \alpha \mathrm{X}$-ray radiation $(\lambda=0.15496 \mathrm{~nm})$. The surface morphology of the sample was revealed by SEM (TESCAN, VEGA3 LMU). The composition of the elements was analyzed by the use of FTIR spectroscopy (PerkinElmer Spectrum RX I) and the optical absorption spectrum of nano $\mathrm{ZnO}$ powder was derived from UV-visible spectroscopy (UV 1800 spectrophotometer, SHIMADZU).

\section{Antimicrobial activity}

The bacterial strains such as E. coli, S. aureus, $K$. pneumoniae, and $S$. aeruginosa were purchased from Microbial Type Culture Collection, Chandigarh, India. Actively growing test bacterial strains were spread on four wells made in the nutrient agar plate. The zinc oxide solution with different concentrations such as 50,100, and $150 \mu \mathrm{g} / \mathrm{ml}$ was loaded in each well, while one well was filled with only broth medium as a control. Then, the plates were incubated at $37^{\circ} \mathrm{C}$ for 24-48 h. Antimicrobial activity was expressed as a diameter ( $\mathrm{mm})$ of the inhibitory zone.

\section{Cytotoxicity assay}

The cytotoxicity assay of the prepared $\mathrm{ZnO}$ nanoparticle was measured using MTT test. The mouse fibroblast (L-929) at a density of $1 \times 10^{6}$ cellll was pipetted into tissue culture with 12 wells, allowed to incubate for $24 \mathrm{~h}$ and treated with different concentrations $(50-500 \mu \mathrm{l} / \mathrm{ml})$ of $\mathrm{ZnO}$ nanoparticles. After the $\mathrm{ZnO}$ nanoparticle treatment, the medium was changed and the cells were washed twice with (Dulbecco's Modified Eagle's Medium/Ham's 12 nutrient mixtures) without fetal calf serum to remove the dead cells. The cells were incubated with $200 \mu 1$

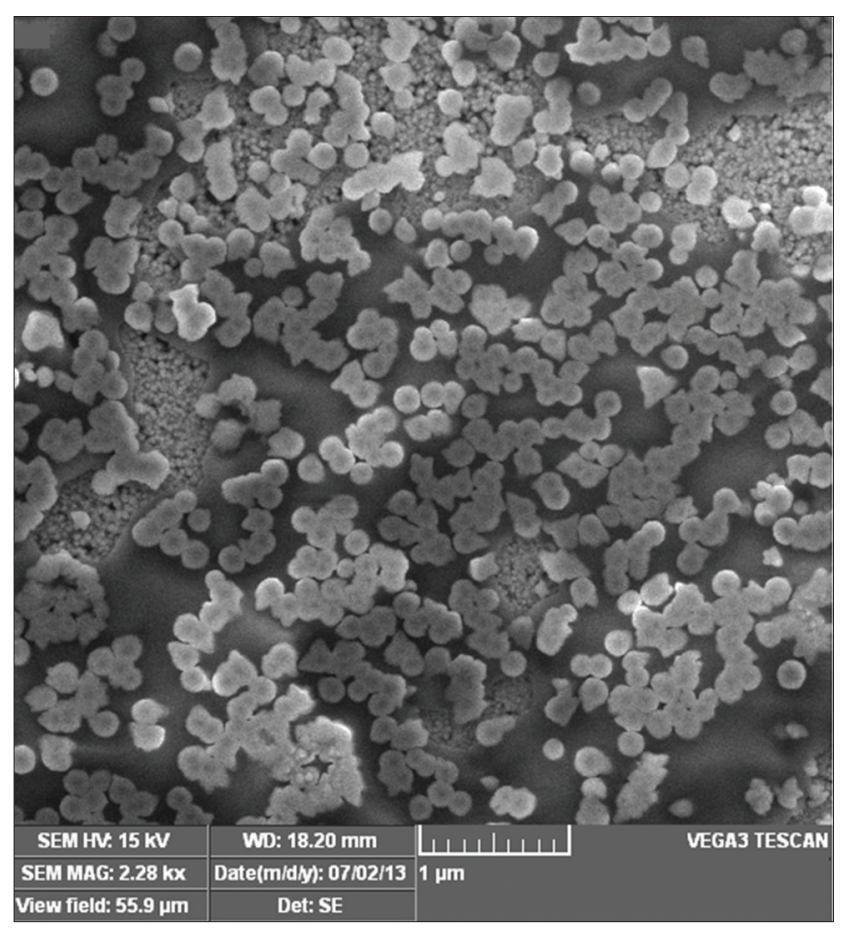

Figure-1: Scanning electron microscopy image of $\mathrm{ZnO}$ nanoparticles. 
$(5 \mathrm{mg} / \mathrm{ml})$ of MTT reagent for $6-7 \mathrm{~h}$ at $37^{\circ} \mathrm{C}$ in $5 \%$ $\mathrm{CO}_{2}$ incubator for cytotoxicity. Tetrazolium salt MTT converted to a colored formazan by the mitochondrial dehydrogenases indicates the presence of viable cells. Color development was measured at $595 \mathrm{~nm}$ using a spectrophotometer. In this assay, cells without nanoparticle attachment were used as a control. The viability of the cell was calculated as follows:

$$
\text { Cell viability }(\%)=\frac{\text { Mean OD }}{\text { Control OD }} \times 100
$$

\section{Results and Discussion}

\section{SEM analysis}

The SEM photograph of the sample is shown in Figure-1. The SEM images of $\mathrm{ZnO}$ samples obtained from the precipitation method revealed the presence

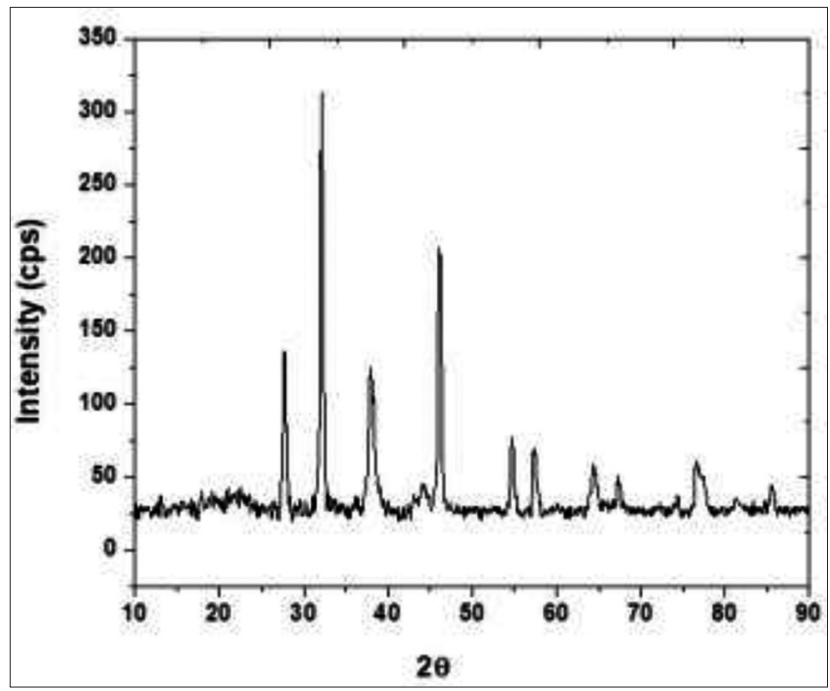

Figure-2: Spectrum of $\mathrm{ZnO}$ nanoparticles obtained by $\mathrm{X}$-ray diffraction spectroscopy. of nanoparticles of spherical shape with minimal agglomeration. A similar structure was observed in $\mathrm{ZnO}$ nanoparticles by Kim and Park [21], Ong et al. [22]. The capping agent might be used to reduce the particle size during precipitation. The particle size varied from 70 to $100 \mathrm{~nm}$ as observed from the SEM image shown below. Reducing the rate of addition of sodium hydroxide with zinc acetate might reduce the particle size formation during precipitation.

\section{XRD studies}

Figure-2 shows the XRD patterns of $\mathrm{ZnO}$ samples. Bragg reflection with $2 \theta$ of A $32.18^{\circ}, 36.78^{\circ}$, and $47.54^{\circ}$ was observed to (100), (101), and (102) planes confirm the presence of $\mathrm{ZnO}$ nanoparticle. Furthermore, the less intense peaks at $48^{\circ}, 54^{\circ}, 57^{\circ}$, $64^{\circ}$, and $77^{\circ}$ ( $2 \theta$ values) indicate the high crystallinity of $\mathrm{ZnO}$ samples and high purity of the $\mathrm{ZnO}$ nanopowders. Crystallite size of the $\mathrm{ZnO}$ samples was calculated using Scherrer's formula. The average particle size of the sample obtained from this precipitation method was calculated using full width at half maximum of more intense peak corresponding to 101 planes located at $32.18^{\circ}$ using Scherrer's formula. The average crystalline size is found to be $74.67 \mathrm{~nm}$. Similarly, XRD pattern was reported by Kim and Park [21], Mohana and Renjanadevi [23], and Jenkins and Snyder [24].

\section{FTIR spectra}

FTIR spectrum of the synthesized $\mathrm{ZnO}$ nanoparticles showed (Figure-3) the fundamental mode of vibration at 3410.69 which corresponds to the $\mathrm{O}-\mathrm{H}$ stretching vibration, 2924.78 which corresponds to $\mathrm{C}-\mathrm{H}$ stretching vibration, and 1377.13 corresponds to $\mathrm{C}=\mathrm{O}$ asymmetric stretching vibration. The peaks 1647.58 and 619.27 correspond to $\mathrm{ZnO}$ stretching and deformation vibration. The absorption at $857 \mathrm{~cm}^{-1}$ is

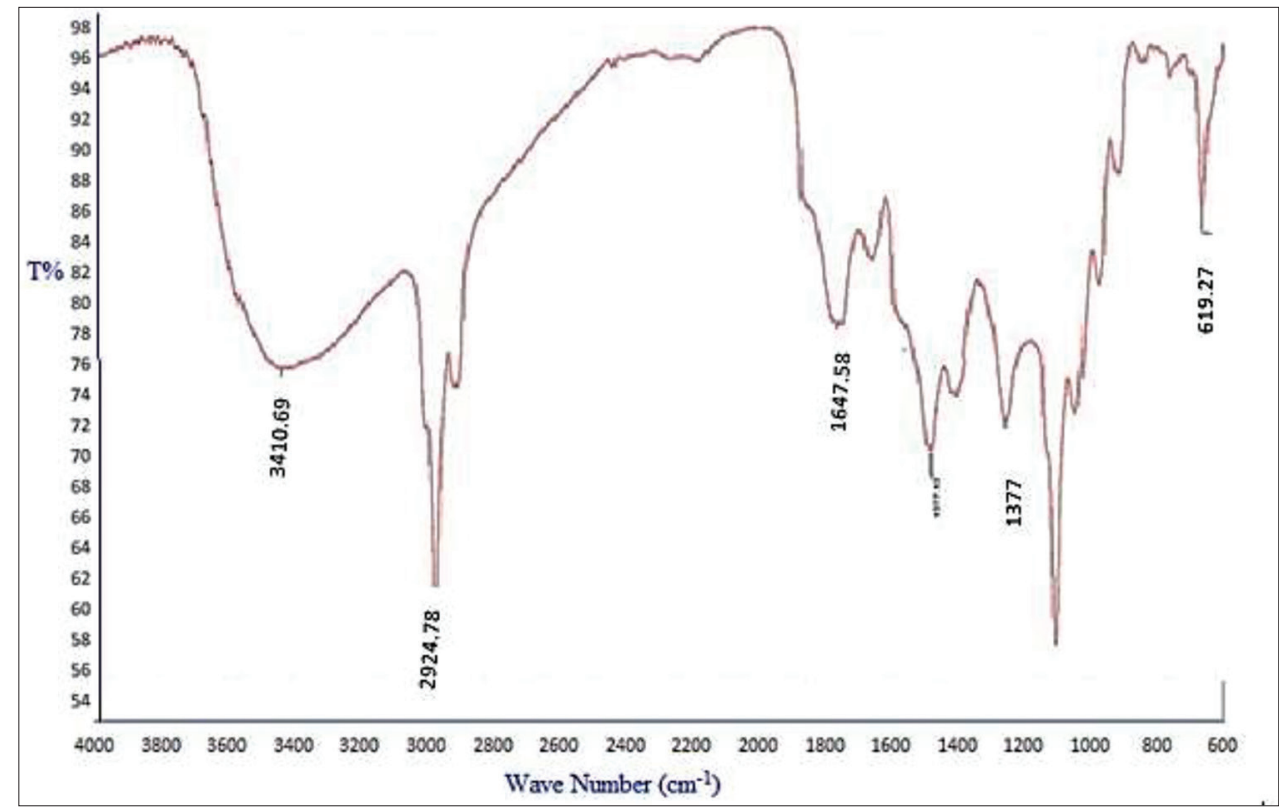

Figure-3: Fourier transform infrared spectra of ZnO nanoparticles. 
Table-1: Antimicrobial activity of nano $\mathrm{ZnO}$.

\begin{tabular}{|c|c|c|}
\hline Bacteria & Concentration $(\mu \mathrm{g} / \mathrm{ml})$ & Zone of inhibition by ZnO nanoparticles $(\mathrm{mm})$ \\
\hline \multirow[t]{3}{*}{ Staphylococcus aureus } & 50 & 14 \\
\hline & 100 & 17 \\
\hline & 150 & 19 \\
\hline \multirow[t]{3}{*}{ Escherichia coli } & 50 & 11 \\
\hline & 100 & 19 \\
\hline & 150 & 24 \\
\hline \multirow[t]{3}{*}{ Klebsiella pneumoniae } & 50 & 07 \\
\hline & 100 & 11 \\
\hline & 150 & 14 \\
\hline \multirow[t]{3}{*}{ Streptococcus aeruginosa } & 50 & 12 \\
\hline & 100 & 15 \\
\hline & 150 & 17 \\
\hline
\end{tabular}

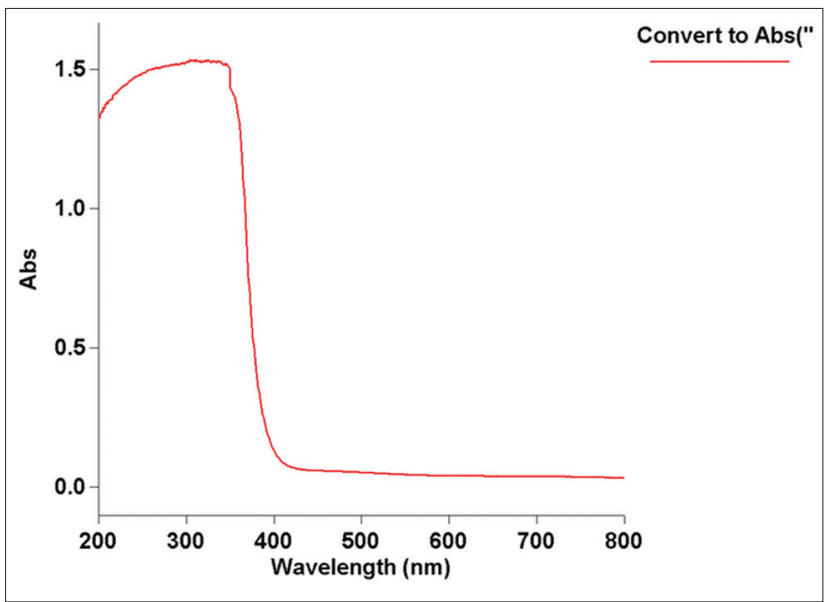

Figure-4: Ultraviolet-visible absorption of the $\mathrm{ZnO}$ nanoparticles.

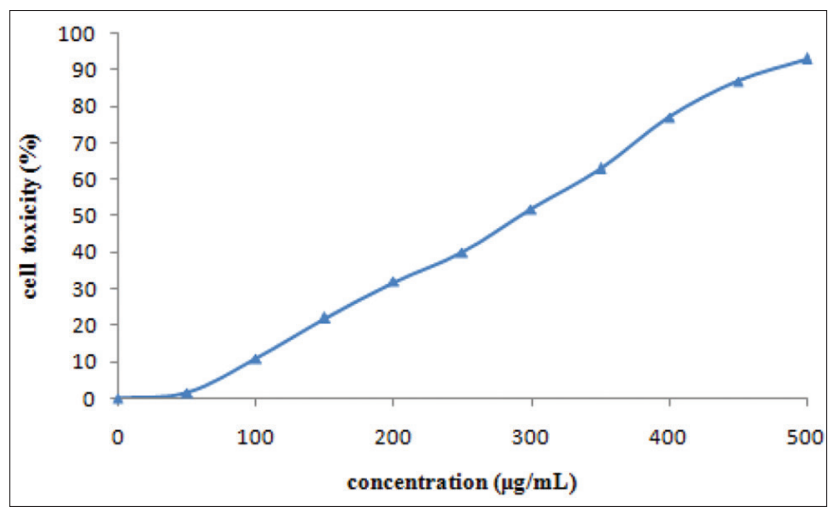

Figure-5: Cytotoxicity of $\mathrm{ZnO}$ nanoparticles on L-929 (mouse fibroblast) cell line.

due to the formation of tetrahedral coordination of $\mathrm{Zn}$. The frequencies observed for the zinc oxides are in accordance with literature values [25-27] reported similar FTIR spectra of zinc oxide nanoparticles in their investigation.

\section{UV-visible absorption spectrum}

UV-visible absorption spectroscopy is a commonly used technique to examine the optical properties of nanosized particles. It is obvious from Figure-4, nano zinc oxide powder exhibits a strong absorption band at about $335 \mathrm{~nm}$, which lies below the bandgap wavelength of $388 \mathrm{~nm}$ of bulk $\mathrm{ZnO}$. The excitation absorption of $\mathrm{ZnO}$ powder and bulk $\mathrm{ZnO}$ material appeared at $\sim 327 \mathrm{~nm}$ and $\sim 373 \mathrm{~nm}$ was reported. The excitation peak at 335 in Figure-4 is similar to the previous report $[28,29]$.

\section{Antibacterial activity}

The antibacterial activity of control along with $\mathrm{ZnO}$ nanoparticles was investigated against pathogenic bacteria such as E. coli, S. aureus, $K$. pneumoniae, and S. aeruginosa. Table-1 pronounces the $\mathrm{ZnO}$ exhibited remarkable antibacterial activity against tested bacterial strains. It has already been proved that nano-sized $\mathrm{ZnO}$ suspensions are active in inhibiting bacterial growth. In the present study, $\mathrm{ZnO}$ nanoparticle was found to have a broad spectrum of antibacterial activity. A significant inhibitory effect rate was observed against the selected bacteria in the order of E. coli, S. aureus, $K$. pneumoniae, and $S$. aeruginosa. It seems that active oxygen species generated by $\mathrm{ZnO}$ nanoparticles could be responsible for the antimicrobial activity. Antibacterial activity of nano $\mathrm{ZnO}$ against $E$. coli has been reported and the reactive oxygen species induced by the nano $\mathrm{ZnO}$ are responsible for inhibiting bacterial growth [20,30].

\section{Cytotoxicity assay}

The cytotoxic effect of $\mathrm{ZnO}$ nanoparticle was determined using mouse epithelial cell L-929 by MTT assay. The cytotoxicity rate was increased with increased concentration of nano $\mathrm{ZnO}$ (Figure-5). A significant cytotoxic effect started from a concentration of $180 \mu \mathrm{g} / \mathrm{ml}$, whereas up to $180 \mu \mathrm{g} / \mathrm{ml}$, the minimal acceptable toxicity level $30 \%$ was observed. Hence, the $\mathrm{ZnO}$ nanoparticle can be used as a feed supplement at a dose rate of up to $180 \mu \mathrm{g} / \mathrm{ml}$.

\section{Conclusion}

The larger particle $\mathrm{ZnO}$ is not commonly used in livestock feed supplementation due to its low bioavailability. However, the nanoparticulated $\mathrm{ZnO}$ can provide a better surface to volume ratio for the physiological digestive mechanism of zinc. Hence, the bioavailability of the zinc might be enhanced by nano $\mathrm{ZnO}$ supplementation than larger particulate $\mathrm{ZnO}$ or zinc methionine supplements. In this context, the 
$\mathrm{ZnO}$ nanoparticles were synthesized by precipitation method using zinc acetate. SEM analyses revealed that the synthesized $\mathrm{ZnO}$ was spherical in shape with a diameter of 70-100 $\mathrm{nm}$. The same size and purity of the sample are revealed by XRD. The nano-sized $\mathrm{ZnO}$ particles exhibited the UV absorption peak at $335 \mathrm{~nm}$. In FTIR spectroscopy, pure ZnO nanoparticles showed stretching vibrations at $4000-5000 \mathrm{~cm}^{-1}$. The antibacterial test proved that the prepared $\mathrm{ZnO}$ can resist the growth of tested bacteria. The cell cytotoxicity study expressed that the lethal dose is only above $180 \mu \mathrm{g} / \mathrm{ml}$. Hence, the antibacterial activity $(150 \mu \mathrm{g} / \mathrm{ml})$ and the cell viability dose level (up to $180 \mu \mathrm{g} / \mathrm{ml}$ ) are unique in the conducted experiment. Hence, it is proposed to conduct the feeding trails in animals with $\mathrm{ZnO}$ nanoparticle to assess their feeding value.

\section{Authors' Contributions}

$\mathrm{KG}$ designed the experiment, synthesized, and characterized the nano $\mathrm{ZnO}$. NA helped in antimicrobial and MTT assay. KG drafted the manuscript. $\mathrm{MC}$ helped in drafting of the manuscript. $\mathrm{MC}$ and $\mathrm{AR}$ reviewed and corrected the manuscript. All authors read and approved the final manuscript.

\section{Acknowledgments}

We acknowledge the financial support for this study by DST Nano Mission (SR/NM/PG-05/2008), India, and Periyar Maniammai Institute of Science and Technology, India.

\section{Competing Interests}

The authors declare that they have no competing interests.

\section{Publisher's Note}

Veterinary World remains neutral with regard to jurisdictional claims in published institutional affiliation.

\section{References}

1. Frassinetti, S., Bronzetti, G.L., Caltavuturo, L., Cini, M. and Croce, C.D. (2006) The role of zinc in life: A review. $J$. Environ. Pathol. Toxicol. Oncol., 25(3): 597-610.

2. Wiering, F.T., Berger, J., Dijkhuizen, M.A., Hidayat, A., Ninh, N.X., Utomo, B., Wasantwisut, E. and Winichaggon, P. (2007) Combined iron and zinc supplementation in infants improved iron and zinc status, but interactions reduced efficacy in a multicountry trial in Southeast Asia. J. Nutr., 137(2): 466-471.

3. Zalewski, P.D., Ai, Q.T., Dion, G., Lata, J., Chiara, M. and Richard, E.R. (2005) Zinc metabolism in airway epithelium and airway inflammation: Basic mechanisms and clinical targets: A review. J. Pharmacol. Ther., 105(2): 127-149.

4. Cao, J., Henry, P.R., Guo, R., Holwerda, R.A., Toth, J.P., Littell, R.C., Miles, R.D. and Ammerman, C.B. (2000) Chemical characteristics and relative bioavailability of supplemental organic zinc sources for poultry and ruminants. $J$. Anim. Sci., 78(8): 2039-2054.

5. Spears, J.W. (1994) Minerals in forages. In: Fahey, G.C Jr., editor. Forge Quality, Evaluation, and Utilization. American Society of Agronomy, Inc., Madison, WI.

6. Elashry, G.M. (2018) Effect of dietary biozinc forms on performance, digestibility coefficient, nutritive value and blood profile in Barki lambs. Int. J. Anim. Sci., 2(1): 1013.

7. Suliman, H.B., Abdelrahim, A.I. and Zakia, A.M. (1988) Zinc deficiency in sheep: Field cases. Trop. Anim. Health Prod., 20(1): 47-51.

8. Alhussien, M.N. and Dang, A.K. (2018) Milk somatic cells, factors influencing their release, future prospects, and practical utility in dairy animals: An overview. Vet. World, 11(5): 562-577.

9. Suttle, N.F. and Jones, D.G. (2000) Micronutrient imbalance. In: Aitken, I.D., editors. Diseases of Sheep. $4^{\text {th }}$ ed. Blackwell Publishing, Oxford, UK. p377-392.

10. Watson, T.D.G. (1998) Diet and skin disease in dogs and cats. J. Nutr., 128(12): 2783-2789.

11. Beigh, S.A., Iqbal, R., Bhat, A.M. and Ishfaq, A. (2017) Management of zinc responsive dermatitis in dogs. $J$. Entomol. Zool. Stud., 5(6): 2569-2571.

12. Fraker, P.J., Gershwin, M.E., Good, R.A. and Prasad, A. (1986) Interrelationships between zinc and immune function. Fed. Proc., 45(5): 1474-1478.

13. Pimentel, J.L., Cook, M.E. and Greger, J.L. (1991) Bioavailability of zinc-methionine for chicks. Poult. Sci., 70(4): 1637-1639.

14. Tawfik, M., Moustafa, M., Abumourad, M.K., El-Meliegy, E. and Refai, M. (2017) Evaluation of Nano Zinc Oxide Feed Additive on Tilapia Growth and Immunity. $15^{\text {th }}$ International Conference on Environmental Science and Technology.

15. Veldkamp, T., van Diepen, J.T.M. and Bikker, P. (2014) The Bioavailability of Four Zinc Oxide Sources and Zinc Sulphate in Broiler Chickens. UR Livestock Research, Wageningen. p806.

16. BIS. (1992) Poultry Feed Specifications," $4^{\text {th }}$ Review, Bureau of Indian Standards, Manak Bhawan. BIS, New Delhi.

17. Zhang, J.S., Gao, X.Y., Zhang, L.P. and Bao. Y.P. (2001) Biological effects of a nano red elemental selenium. Biofactors, 15(1): 27-38.

18. Yusof, H.M., Mohamad, R., Zaidan, U.H. and Rahman, N.A.A. (2019) Microbial synthesis of zinc oxide nanoparticles and their potential application as an antimicrobial agent and a feed supplement in the animal industry: A review. J. Anim. Sci. Biotechnol., 10: 57.

19. Yazdankhah, S., Rudi, K. and Bernhoft, A. (2014) Zinc and copper in animal feed-development of resistance and co-resistance to antimicrobial agents in bacteria of animal origin. Microb. Ecol. Health Dis., 25: 1.

20. Rajendran, D. (2013) Application of nano minerals in animal production system. Res. J. Biotechnol., 8(3):1-3.

21. Kim, S.Y. and Park, D.H. (2009) Preparation of $\mathrm{ZnO}$ nanopowders by thermal plasma and characterization of photo-catalytic property. Appl. Surf. Sci., 255(10): 5363-5367.

22. Ong, C.B., Ng, L.Y. and Mohammad, A.W. (2018) A review of $\mathrm{ZnO}$ nanoparticles as solar photocatalysts: Synthesis, mechanisms and applications. Renew. Sustain. Energy Rev., 81(1): 536-551.

23. Mohana, A.C. and Renjanadevi, B. (2016) Preparation of zinc oxide nanoparticles and its characterization using scanning electron microscopy (SEM) and X-ray diffraction (XRD). Procedia Technol., 24(2016): 761-766.

24. Jenkins, R. and Snyder, R.L. (1970) Introduction to X-ray Powder Diffractometry. John, Wiley \& Sons, New York.

25. Chena, B., Yu, P., Liu, J., Liu, F. and Wang, L. (2011) Investigation of nano-sized $\mathrm{ZnO}$ particles fabricated by various synthesis routes. J. Ceram. Process. Res., 12(4): 420-425.

26. Deneva, M. (2010) Infrared spectroscopy investigation of metallic nanoparticles based on copper, cobalt, and nickel synthesized through borohydride reduction method (review). J. Univ. Chem. Technol. Metall., 45(4): 351-378.

27. Estrada-Urbina, J., Cruz-Alonso, A., SantanderGonzález, M., Méndez-Albores, A. and Vázquez-Durán, A. 
(2018) Nanoscale zinc oxide particles for improving the physiological and sanitary qality of a Mexican landrace of red maize. Nanomaterials (Basel), 8(4): 247.

28. Parthasarathi, V. and Thilagavathi, G. (2011) Synthesis and characterization of zinc oxide nanoparticle and its application on fabrics for microbe-resistant defense clothing. Int. J. Pharm. Sci., 3(4): 1-7.
29. Getie, S., Belay, A., Reddy, A.R. and Belay, Z. (2017) Synthesis and characterizations of zinc oxide nanoparticles for antibacterial applications. J. Nanomed. Nanotechnol., 10(6): S8.

30. Qiang, J.L., Xu, Z.L., Jing, S., Xiaojun, S. and Weimin, C. (2002) The preparation and characterization of $\mathrm{ZnO}$ ultrafine particles. Mater. Sci. Eng. A, 232(1/2): 356-361.

$* * * * * * * *$ 